\title{
Structures of the Mixed Layer and Estimates of Sea Surface Fluxes during TOGA-COARE IOP
}

\author{
Part I: Structures of the Mixed Layer
}

\author{
By Y.H. Ding ${ }^{1}$, Akimasa Sumi and X.S. Shen \\ Center for Climate System Research, University of Tokyo 4-6-1 Komaba, Meguro-ku, Tokyo, Japan 153
}

(Manuscript received 18 May 1994, in revised form 26 November1994)

\begin{abstract}
The surface and aerological observations made by the Japanese research vessel Hakuho-maru on 11-27 November, 1992 at $0^{\circ}, 156^{\circ} \mathrm{E}$ during TOGA-COARE IOP period were used to analyze the evolution and structure of mixed layer over the ocean, and to estimate surface fluxes by using bulk schemes. The Part I of this study is devoted to the problem of the mixed layer. The main finding is that the regional wind field can greatly modify the structure of the mixed layer. For the east trade régime, the mixed layer had a relatively great depth, mostly reaching $800-900 \mathrm{~m}$. Above this level was a dry layer without any significant inversion. For the west wind régime created by four westerly wind bursts, the height of the mixed layer was considerably depressed, or even disappeared. A deep saturation layer was often observed.

Two events of the intrusion of the extremely dry air layer greatly enhanced and elevated the mixed layer, up to about $1.5 \mathrm{~km}$. The reason for these events was discussed.
\end{abstract}

\section{Introduction}

The TOGA-COARE domain is selected as an area from $140^{\circ} \mathrm{E}$ to $180^{\circ}$ and from $10^{\circ} \mathrm{N}$ to $10^{\circ} \mathrm{S}$. The domain sits within the warm pool region during the entire year. Due to the widespread convective activity and related precipitation over the warm pool region, a significant atmospheric heating (or heat source) is produced which may exert an important effect on the regional or large-scale tropical circulation from the viewpoint of thermal forcing. The exchange of heat energy and momentum between the sea and the atmosphere is carried out through their interface, that is, a marine boundary layer. Therefore, the evolution and structures of the boundary layer are directly related to this interface exchange process and further upward transport in the boundary layer.

On the other hand, from the perspective of air flow or wind field, the TOGA-COARE domain has also a unique large-scale feature. It is observed that an interaction between westerly wind and the east trade wind occurs at lower levels. In the Northern Hemisphere summer, the summer westerly monsoon is full-developed and often extends into this

1 On leave from Chinese Academy of Meteorological Sciences, Beijing 10081, China

(C) 1995, Meteorological Society of Japan region, with a marked convergence zone (ITCZ) existing north of there. In winter, the northeast and southeast trades intensify and undergo a significant westward penetration and the strong convergence move westward into the western part of Indonesia. In the Southern Hemisphere the uniform southeasterly flow has retreated to $20^{\circ} \mathrm{S}$ (Barnett, 1983) and establishes strong convergence zones off the east coast of northern Australia. Therefore, most of the COARE domain is normally dominated by the easterly trades. In the context of this kind of large-scale air flow, this region is usually characterized by a multi-layered structure of the atmospheric boundary layer. Numerous researchers have investigated the structures and physical processes within the trade wind zones over the tropical Pacific (Riehl, Yeh and Malkus, 1951). They found that, in these regions, there is a net input of heat and moisture from the ocean into the atmosphere. Excess energy accumulating below the trade inversion is transported downstream into the ITCZ where heat is released in deep convective clouds.

Based on recent observations (Chu,1988; Lau, Nakazawa and Sui, 1991; Delcroix et al., 1993), the relatively stable trade wind flow in this region is sometimes interrupted by the "westerly wind bursts", which appear to follow the movement of the super cloud cluster systems. When these super 
cloud cluster systems move, generally from west to east with a low-frequency mode, into the COARE domain, they greatly enhance the convective activity in this region, and episodically change the structure of regional wind field. In this context, the atmospheric boundary layer could be correspondingly modified, with a considerable variation from the normal trade-type boundary layer. These anomalous conditions may not only affect the processes of energy cycle in the regional sense, but also are taken as some kind of triggering mechanism for the ENSO event (Wyrtki, 1975). Therefore, an examination of the evolution and structures of the boundary layer and its related surface fluxes is of great importance and special implication. This is the major goal of this study. The present paper is the first part of our study, mainly devoted to the observational aspect of the mixed layer over the TOGA-COARE domain in November of 1992. The second part will be directed towards estimating the ocean surface fluxes with a special emphasis of their short-term variability and episodic fluctuations (Ding et al., 1995). With this study, one may gain an insight into features of the planetary boundary layer during the TOGA-COARE IOP.

\section{Data Sources and Definition of the Mixed Layer}

The atmospheric omegasonde observations were routinely conducted on board $\mathrm{R} / \mathrm{V}$ Hakuho-maru for the time period of 1 November-3 December, 1992, measuring the atmospheric pressure, temperature, relative humidity, dew point temperature, wind direction and speed in the atmosphere (Asai et al., 1993). The ceiling of many omegasondes often reached 50 or even $30 \mathrm{hPa}$. The accuracy and resolution of these observations were sufficient to motivate the analyses presented herein. During the entire observational period, the cruise was divided into two legs. Leg 1 spanned from 1 to 6 November, 1992, while the ship made a cruise from Cairns, Australia to Rabaul, Papua New Guinea. The second leg for 11-27 November, 1992 is the nearly stationary observation located at $\left(0^{\circ}, 156^{\circ} \mathrm{E}\right)$ just north of the IFA (Intensive Flux Area), whose center location is $\left(2^{\circ} \mathrm{S}, 156^{\circ} \mathrm{E}\right)$. It is recognized that continuous upperair soundings are very vital for documenting the horizontal and vertical structure of the boundary layer in the vicinity of deep precipitating systems. During this time period, the omegasounding observations were upgraded to four or eight times on a daily basis. The enhanced frequency of omega soundings provided a good opportunity to monitor the rapid changes in the upper air wind field, in particular the onset of westerly wind bursts and diurnal variations of the boundary layer. As we are interested in the evolution and structure of the tropical boundary layer, our study will be concentrated on the obser- vation at the fixed site $\left(0^{\circ}, 156^{\circ} \mathrm{E}\right)$. Two data sets derived on the cruise to and from the fixed site will be also used for comparison to examine the regional differences in the atmospheric boundary layer.

Twice-daily (00 and 12 GMT) grid-point data (1.875 latitude/longitude horizontal resolution) from the global objective analysis (GANAL) of the Japan Meteorological Agency (JMA) for the TOGACOARE IOP period were used in the present study. The data include the zonal wind component (U) and meridional wind component $(\mathrm{V})$, temperature $(\mathrm{T})$, dew point temperature depression $\left(\mathrm{T}-\mathrm{T}_{\mathrm{d}}\right)$ and the geopotential height $(\mathrm{Z})$ or the sea-level pressure $\left(\mathrm{P}_{\mathrm{s}}\right)$ for 11 vertical levels (the surface, 1000, 850, 700, 500, 400, 300, 250, 200, 150 and $100 \mathrm{hPa}$ ). Sounding data collected from various sources during TOGA-COARE IOP have been assimilated into JMA GANAL, including a considerable number of special sounding observations made by five research ships (Ding and Sumi, 1995).

The air properties in the boundary layer of the marine atmosphere are distinctly modified by frictional or thermal influences of the sea surface. A considerable vertical mixing below the capping trade inversion exists, thus creating a mixed layer where some physical properties keep nearly constant with height. The top of the mixing layer often characterizes the cloud base, marked by a discontinuity in potential temperature $(\theta)$, equivalent potential temperature $\left(\theta_{e}\right)$, specific humidity $(q)$ and dry and moist total static energy ( $\mathrm{s}$ and $\mathrm{h}$ ). If one examines the $\theta$-profile in more detail, the mixed layer may be further divided into two sub-layers. The lower layer corresponds to a sub-cloud layer with almost constant $\theta$ and the upper layer corresponds to a cloud layer with a weak vertical gradient of $\theta$ (Nitta and So, 1980). The top of the cloud layer is often capped by an inversion layer, marked by a rapid increase of $\theta, \theta_{e}, \mathrm{~s}$ and $\mathrm{h}$, and a rapid decrease of q. Under conditions of precipitating clouds or tropical disturbances, the mixed-layer depth decreases remarkably. To define the height of a mixed layer, a few of the physical quantities are used from various literature. These quantities include the potential temperature, specific humidity, equivalent potential temperature, virtual potential temperature $\left(\theta_{v}\right)$ and dry and moist total static energy. $\theta_{v}$ accounts for the effects of water vapor density on buoyancy, and the $\theta_{e}$ incorporates the latent heat content of the water vapor. Recently, Bond (1992) used $\theta_{v}$ to define the atmospheric mixed layer in eastern equatorial Pacific, which is characterized by a layer of constant $\theta_{v}$.

\section{Temporal Variation of the Mixed Layer}

In order to understand the environmental condition in which the ship aerological observations were conducted, it is useful to show the mean large-scale 
(a)

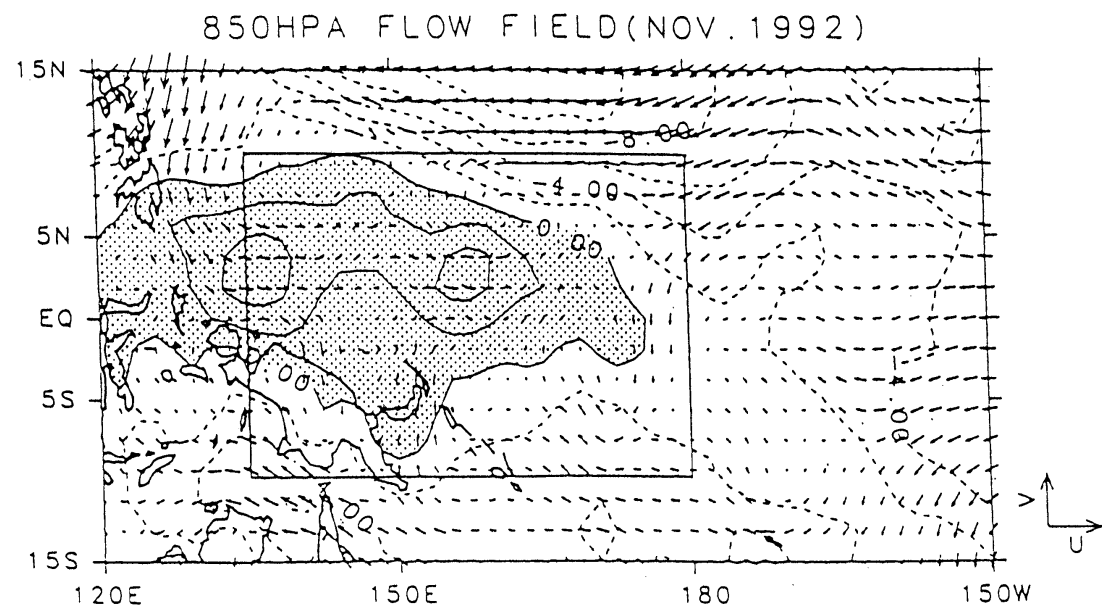

(b)

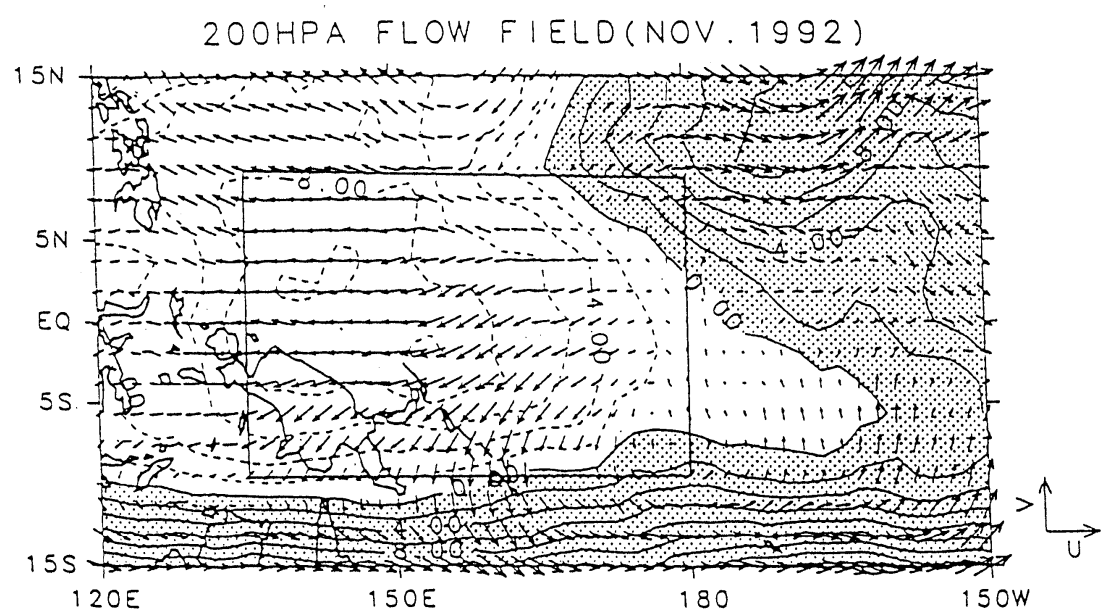

Fig. 1. (a) Mean $850 \mathrm{hPa}$ flow pattern for November, 1992. Westerly wind regions are shaded. Isotachs are denoted by a thin full line (westerly) and a dashed line (easterly). The rectangle region denotes the TOGA-COARE domain. Units are $\mathrm{m} / \mathrm{s}$ and the contour interval is 1.5 units. (b) Same as Fig. 1a, but for a mean $200 \mathrm{hPa}$ flow pattern. The westerly regions are shaded. The unit are $\mathrm{m} / \mathrm{s}$, and the contour interval is 2 units.

airflow fields for November of 1992 (Fig. 1). At $850 \mathrm{hPa}$ (Fig. 1a), a mean westerly wind prevailed over most of the TOGA-COARE domain. It can be seen that a near-equatorial tongue of westerlies appeared to penetrate from the west into this region, terminating at about $175^{\circ} \mathrm{E}$. The easterly wind was weak, mostly confined to a small area of over the eastern portion of this region. The occurrence of the prevailing west wind is closely related to the formation and passage of 3-5 day period tropical disturbances to north of $5^{\circ}-10^{\circ} \mathrm{N}$. In particular, two typhoons formed and intensified during 16-18 November, thus leading to a significant enhancement of the westerly wind over the equatorial region to the south of the typhoons. Note a mean cyclonic circulation, centered around $10^{\circ} \mathrm{N}, 162^{\circ} \mathrm{E}$, which is a clear reflec- tion of activity of these tropical cyclones. Therefore, the typical trade wind condition that normally exists over the central and eastern equatorial Pacific was vigorously disturbed in this month. This large-scale airflow background should be taken into account in the analysis of the mixed layer. At $200 \mathrm{hPa}$ (Fig. 1 b), the COARE domain was characterized by a consistently easterly wind. The airflow was evidently divergent, streaming out of the eastern part of the COARE domain. (see, Ding and Sumi (1995)).

Figure 2 is the time-height cross-section of the zonal component of wind observed by the $\mathrm{R} / \mathrm{V}$ Hakuho-maru fixed at $0^{\circ}, 156^{\circ} \mathrm{E}$ during $11-27$ November, 1992. It is quite evident that the easterly trade wind field was interrupted by four episodes of westerly wind, the second and third ones (15-20 


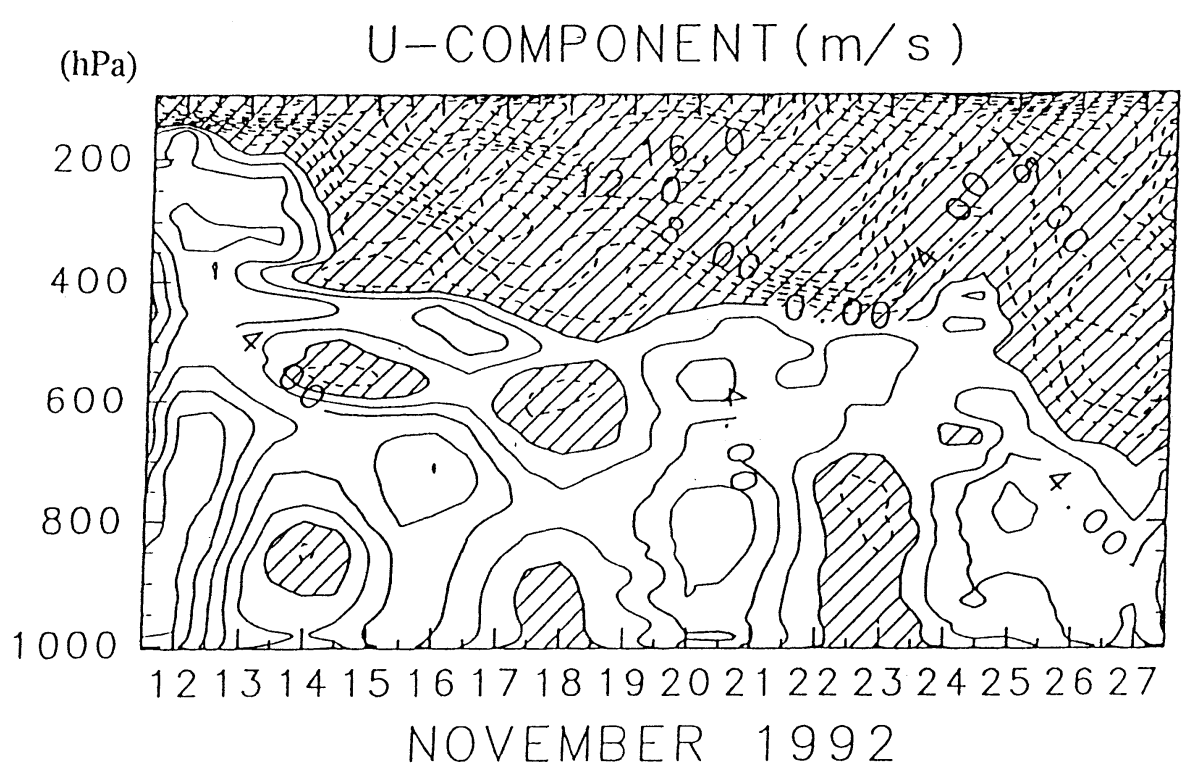

Fig. 2. Temporal variation of the profile of the zonal wind observed by the R/V Hakuho-maru at $0^{\circ}$, $156^{\circ} \mathrm{E}$ for $11-27$ November, 1992 . The easterly regions are shaded. The units are $\mathrm{m} / \mathrm{s}$ and the contour interval is 2 units.

November) of which were caused by two typhoons located around $10^{\circ} \mathrm{N}$. The westerly wind extended upward to the middle troposphere, with the maximum wind generally located in the layer of 800 $700 \mathrm{hPa}$. The meridional wind component had similar fluctuations, generally with a west wind episode corresponding to a south wind, and an east wind episode corresponding to a north wind, but with about one day lagging for the latter. This intrusion of a westerly wind will greatly modify the evolution and structure of the mixed layer.

The existence of the mixed layer is well documented by potential temperature and moisture fields. Figures $3 \mathrm{a}$ and $3 \mathrm{~b}$ show the time-height crosssection of $\theta$ and $\mathrm{q}$, respectively. The mixed layer is characterized by constant $\theta$ and/or q layer. Therefore, in the $\theta$-cross-section, the contour line of $302^{\circ} \mathrm{K}$ can be considered to correspond to the height of the mixed-layer. The height of the mixed layer shows a temporal evolution. It increases around 14-15, November, decreases between 16 and 22 November, and again increases around 24, November. These features are more clearly noted in the time-sequence of the q field. Two peak heights of the mixed layer were roughly in coincidence with the occurrence of the northeast trade, while its lower height corresponds to the episode of a strong west wind caused by the typhoons. The rapid increase of $\theta$ and rapid decrease of $q$ represent the presence of an inversion. It can be found that these rapid vertical changes of $\theta$ and q mainly occurred during the two periods of maximum height of the mixed layer. The height of the mixed layer ranged from $950 \mathrm{hPa}(\sim 400 \mathrm{~m})$ to $900 \mathrm{hPa}$ ( around $800 \mathrm{~m})$. In the individual case (for 14-15 November), it even extended up to about $850 \mathrm{hPa}(\sim 1500 \mathrm{~m})$ (see Fig. 3b and Fig. 4).

A salient feature of Fig. $3 \mathrm{~b}$ is the occurrence of two dry spells in the lower troposphere on 13-15 November and 24-26 November, respectively, with the first being more significant. Their formation will be dealt with in Section 5 .

The time sequence of the equivalent potential temperature (Fig. 4) shows a similar evolutional trend. A constant $\theta_{e}$ layer clearly represents the atmospheric mixed layer. For the two spells of dry layer (13-15 November and 25-26 November), the $\theta_{e}$ profiles show an abrupt decrease just above the mixed layers, characterizing the existence of the dry layer. Next, further discussion will be given to elaborate the detailed features of structures of the mixed layer on the basis of selected typical cases.

\section{Structures of the Mixed Layer for Selected Cases}

A complete set of profiles of $\mathrm{T}_{\mathrm{d}}, \mathrm{q}, \mathrm{RH}$ (the relative humidity), $\theta, \theta_{e}, \theta_{e}{ }^{*}$ (saturation equivalent potential temperature), s (static energy), h (moist static energy) and $h_{\mathrm{s}}{ }^{*}$ (saturation moist total static energy) for each observation of the time period of 1 November-3 December, 1992 were computed. In addition, the pressure, height, temperature and specific humidity at the lifting condensation level (LCL) were also estimated. Having examined this large volume of data, some typical cases were selected to illustrate the structures of the mixed layer representative of this period and location, rather than to make mean profiles by a compositing method, because much detail would be otherwise lost. Below, 
(a)

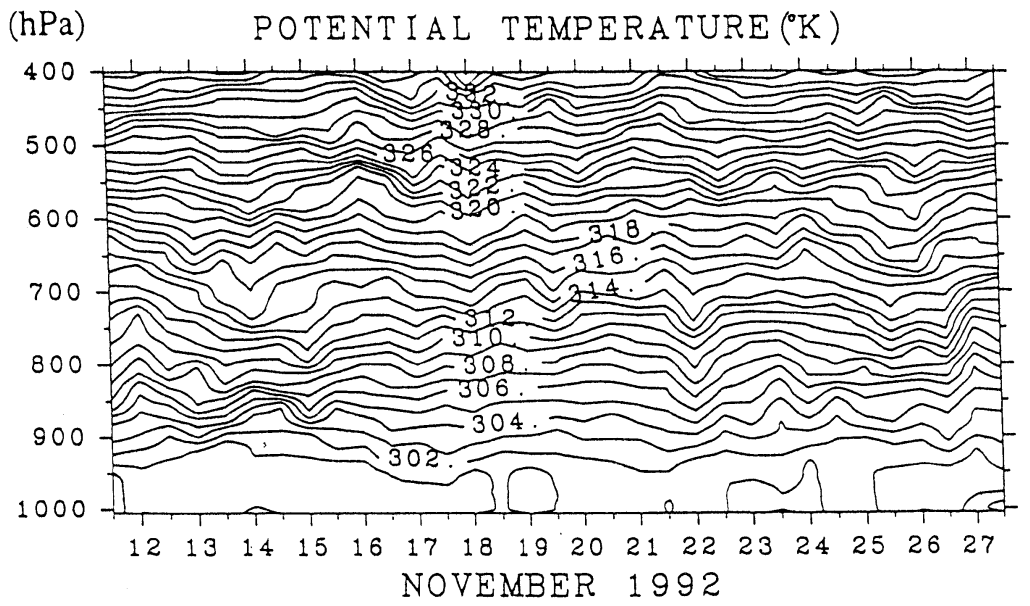

(b)

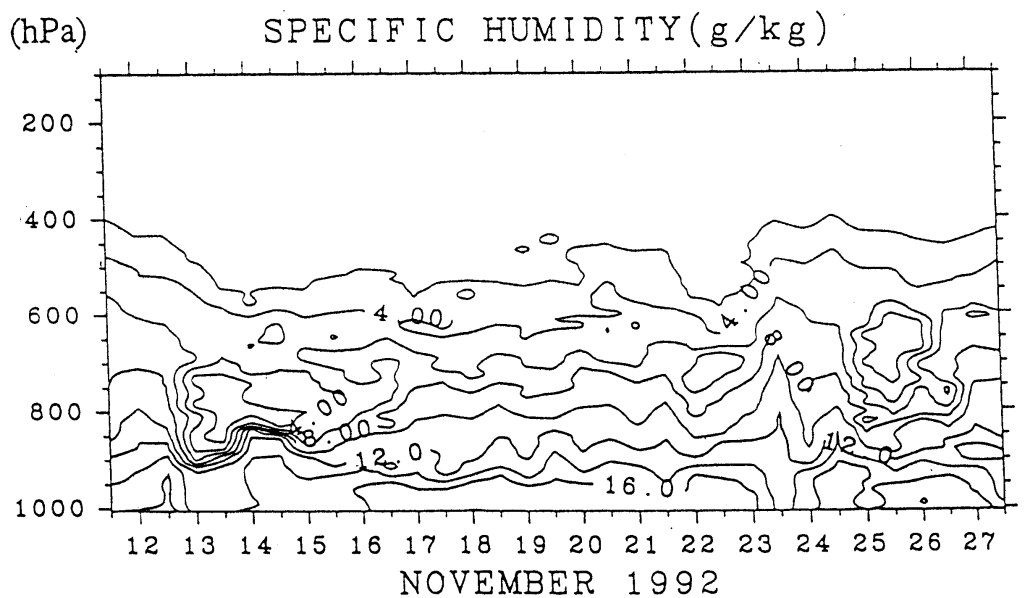

Fig. 3. Temporal variation of the potential temperature at $0^{\circ}, 156^{\circ} \mathrm{E}$ for $11-27$ November, 1992 . The units are $\mathrm{K}$ and the contour interval is 1 unit.

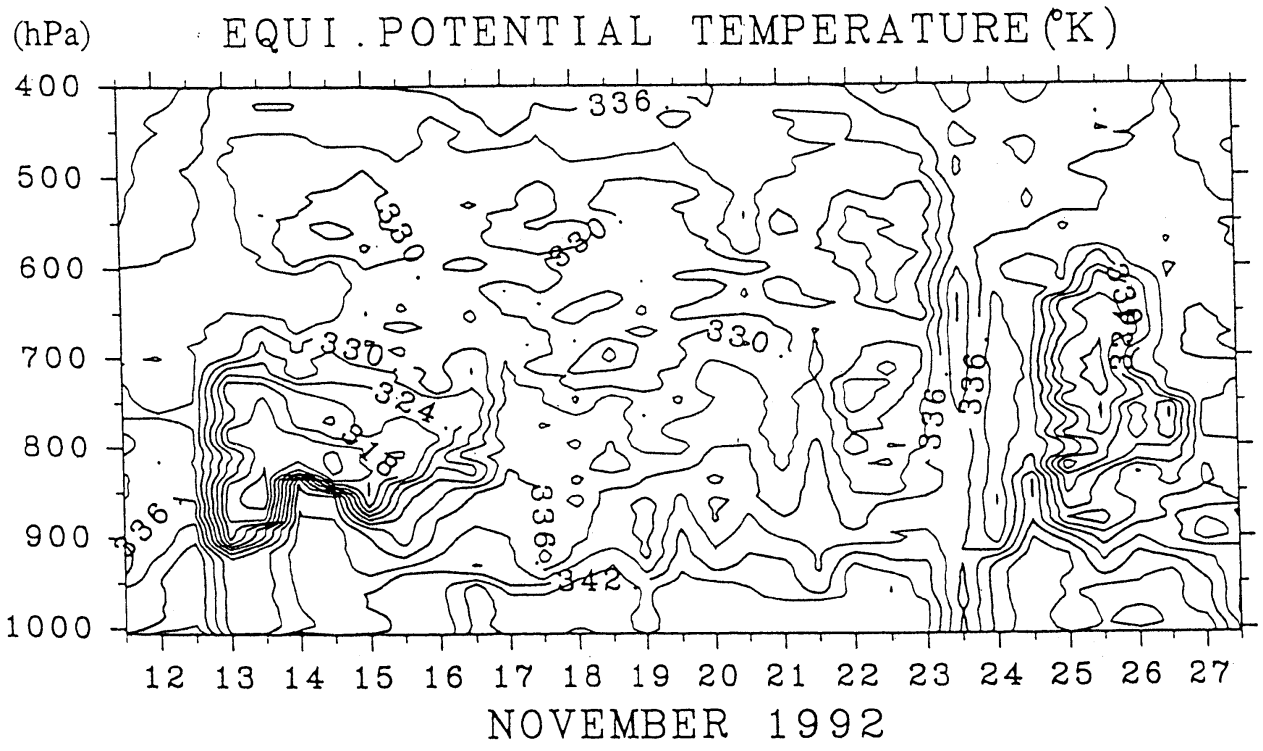

Fig. 4. Time sequence of the selected (00 and 12 Local Standard Time (LST) for each day) profiles of the equivalent potential temperature at $0^{\circ}, 156^{\circ} \mathrm{E}$ for $11-27$ November, 1992 . The units are $\mathrm{K}$ and the contour interval is 2 units. 
(a)

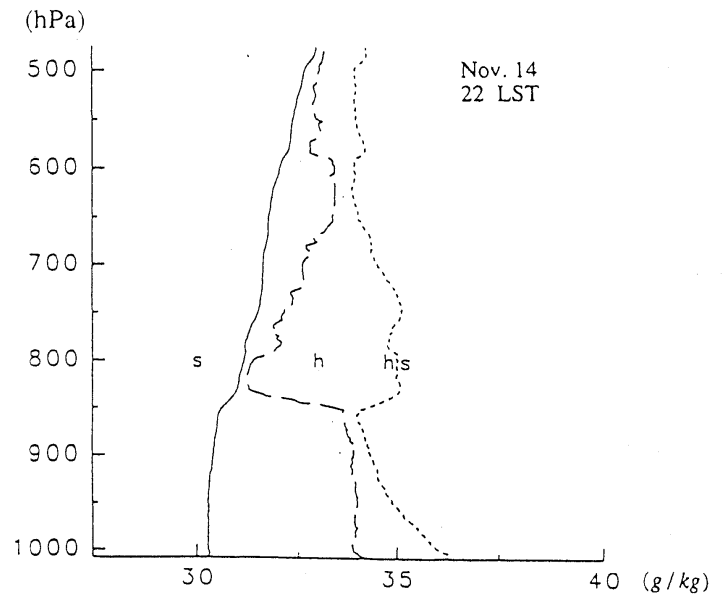

(b)

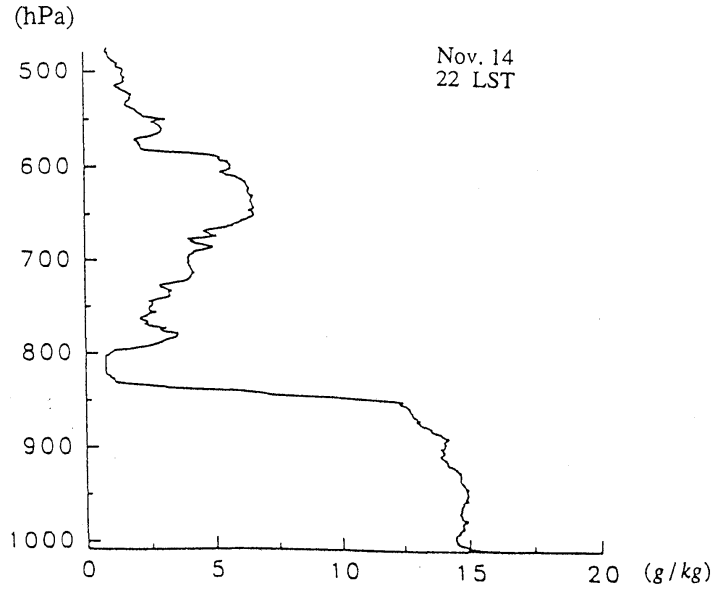

Fig. 5. (a) Profiles of s (full), h (heavy dashed line) and $h_{\mathrm{s}}$ (thin dashed) at 22 LST (LST $=$ GMT +10 hrs) 14 November, 1993 at $0^{\circ}, 156^{\circ}$. Unit is $10 \mathrm{~J} / \mathrm{g}$. (b) Same as Fig. 5a, except for the q. The units are $\mathrm{g} / \mathrm{kg}$.

the plots of $\mathrm{s}, \mathrm{h}$ and $\mathrm{h}_{\mathrm{s}}$ described the thermodynamic structure.

In general, three types of structures of mixed layer have been classified. The first type represents the condition of the existence of a dry layer in the lower and middle troposphere (Fig. 5 and Fig. 6). The dry layers on 13-15 November were mainly found in the layer of $850-650 \mathrm{hPa}$, with an extremely dry condition around $800-820 \mathrm{hPa}(\sim 1 \mathrm{~g} / \mathrm{kg})$, which was accompanied by a thin inversion (see, Fig. 5). Below the base of the dry layer or cloud top $(850 \mathrm{hPa})$, there is a significant mixed layer, with $\mathrm{s}, \theta$ and $\mathrm{q}$ keeping nearly constant with height. But, a careful examination may lead to a further division of this mixed layer into two sub-layers. The upper one from $920 \mathrm{hPa}$ to $850 \mathrm{hPa}$, with weak vertical gradient of (a)

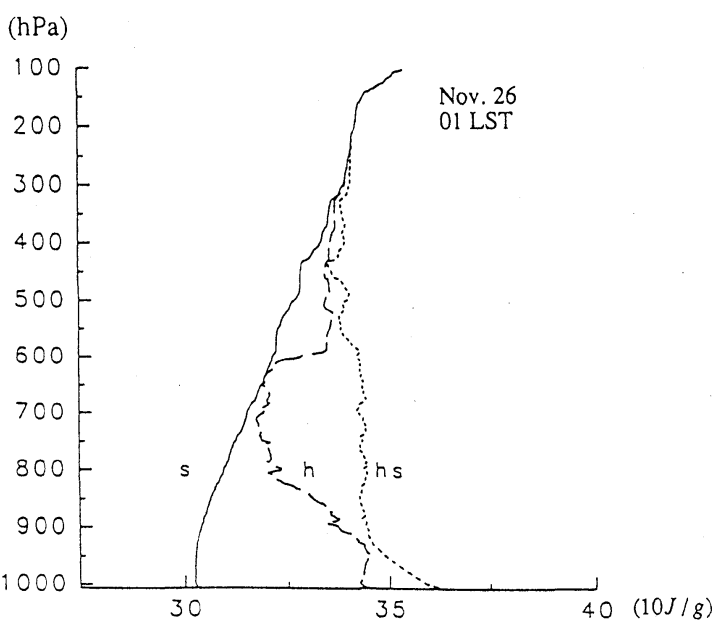

(b)

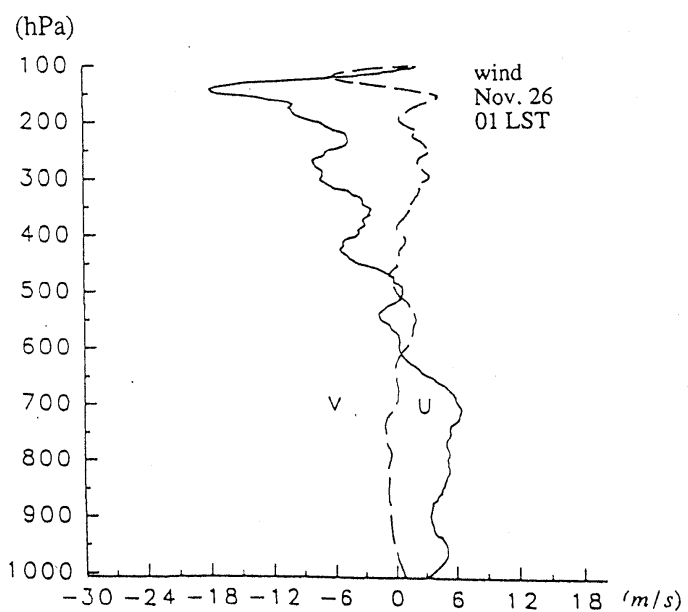

Fig. 6. (a) Same as Fig. 5a, but for $01 \mathrm{LST}$, 26 November, 1992. (b) Same as Fig. 5b, except for zonal (U) and meridional (V) winds of 01 LST, 26 November, 1992.

s (increasing with height), corresponds to a cloud layer, and the lower one from the surface to $920 \mathrm{hPa}$ with constant s, $\mathrm{q}$ and $\mathrm{h}$ corresponds to a sub-cloud layer which is well mixed (Nitta and So, 1980). The LCL is equal to $\sim 924 \mathrm{hPa}(760 \mathrm{~m})$, nearly coincident with the cloud base $(\sim 920 \mathrm{hPa})$. The wind was also mixed (not shown), with the zonal wind component having the maximum at $970 \mathrm{hPa}$, an often observed phenomenon in the mixed layer.

Another dry layer, occurring on 25-26 November, was slightly weaker than the first one, with a lower mixed layer (below $920 \mathrm{hPa}$ ). A thin cloud layer is likely to exist above $950 \mathrm{hPa}$ and below $850 \mathrm{hPa}$ (see, Fig. 6). Note the well-mixed wind field below $700 \mathrm{hPa}$ and a zonal wind component maximum at $950 \mathrm{hPa}$. The difference in structures of the mixed layer between two periods of the dry layer is possi- 
(a)

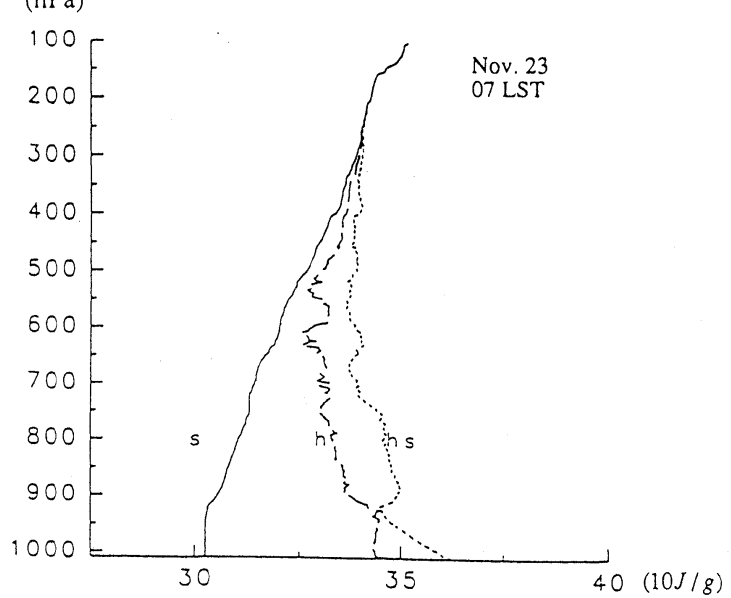

(b)

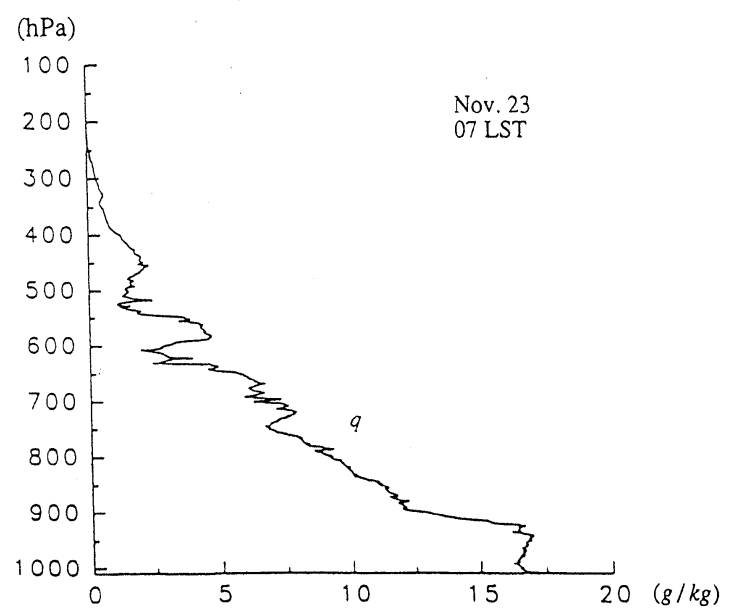

Fig. 7. (a) Same as Fig. 6a, except for 07 LST, 23 November, 1992. (b) Same as Fig. $5 \mathrm{~b}$, buf for 07 LST, 23 November, 1992.

bly attributed to that of wind field. The early one was accompanied by an east wind and dry weather which broadly assumed the feature of the trade type mixed layer, while the later one was accompanied by a strong west wind and strong rainfall, which may decrease the depth of marine mixed layer through the activity of precipitating clouds. The LCL in this case was $944 \mathrm{hPa}(558 \mathrm{~m})$.

The second type of the mixed layer has a lower depth than the first one, and was mainly observed during the east wind régime (Fig. 7). It appears to represent a normal trade-type mixed layer. The height of the mixed layer reached $910-900 \mathrm{hPa}$, with nearly constant $\mathrm{s}$ and $\mathrm{q}$ below this level. The LCL is $947 \mathrm{hPa}(559 \mathrm{~m})$, with a near-saturation layer below $900 \mathrm{hPa}$. Therefore, a trade cloud layer pos- (a)

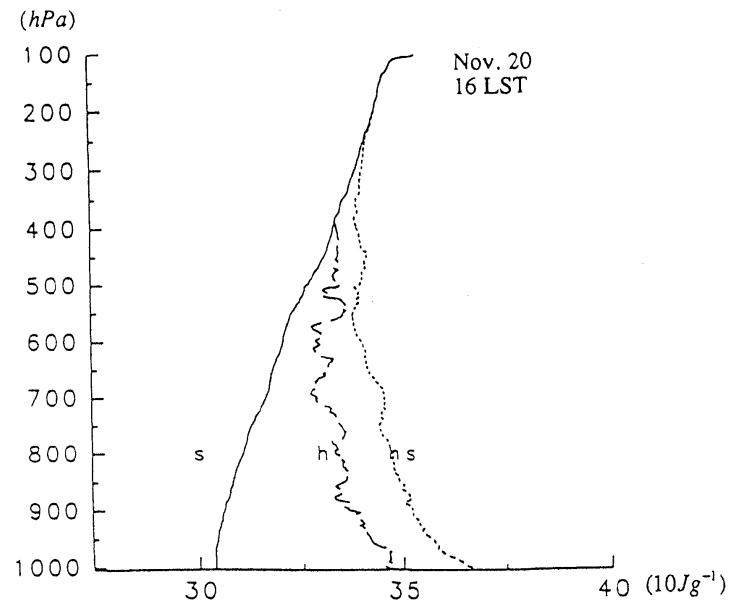

(b)

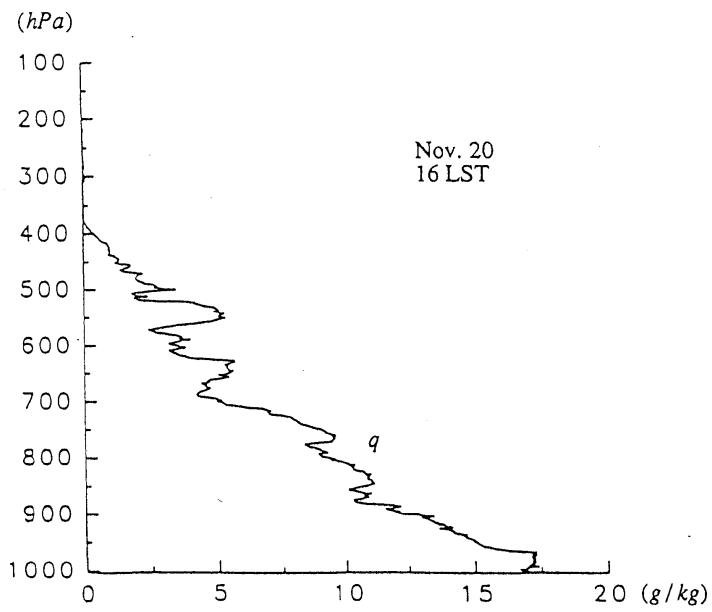

Fig. 8. (a) Same as Fig. 6a, except for 16 LST, 20 November, 1992. (b) Same as Fig. 5b, except for 16 LST, 20 November, 1992.

sibly existed in the layer of $50 \mathrm{hPa}$ thick. Above $900 \mathrm{hPa}$, a deep dry layer capped the cloud top, but was considerably weaker than the first type. The moisture (Fig. 7b) assumed a normal monotonic decrease, without any anomalous intrusion of dry layer in some layers. The structure of the mixed layer of this kind is broadly similar to that under the undisturbed condition of the trade winds.

The third type represents the structure of the mixed layer under the disturbed condition, with frequent interruption of the east trade due to the westerly wind occurrence. As revealed by numerous investigators (Brummer, 1978), strong time and space variations of the mixed layer were observed under the condition of disturbances such as the ITCZ, precipitating clouds and tropical storms. Normally, the depth of mixed layers decreases, with a simultaneous 
(a)

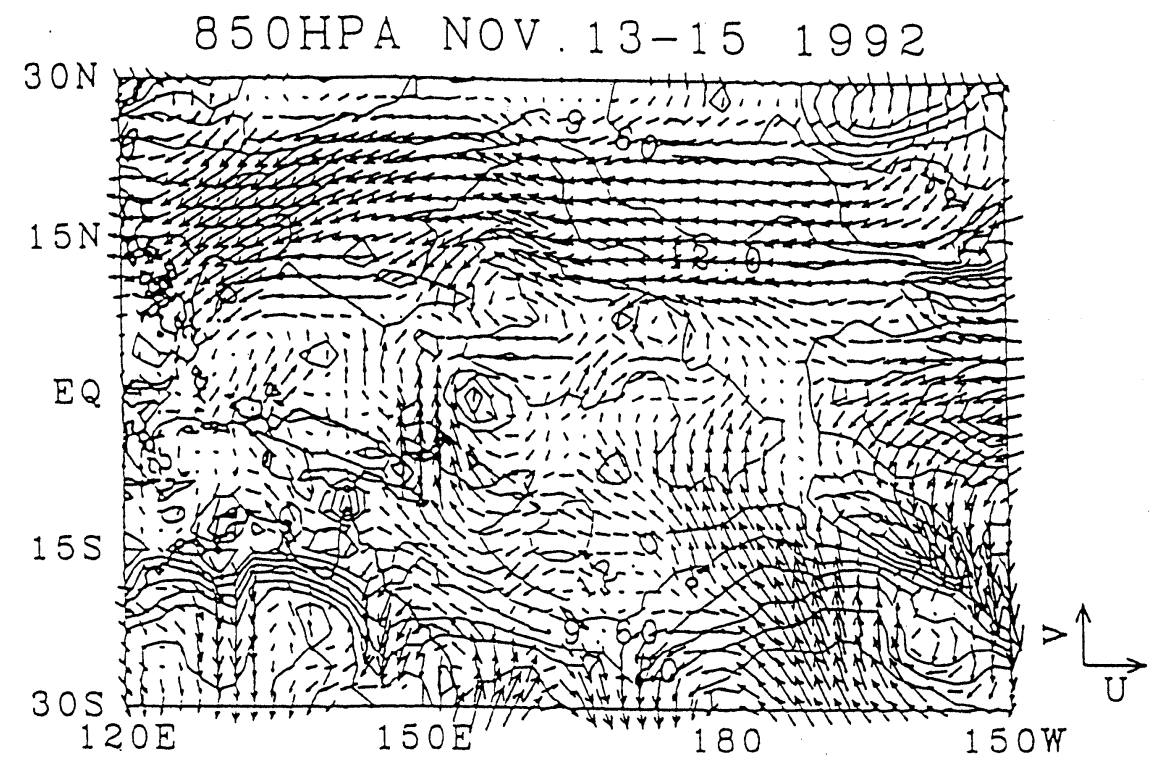

(b)

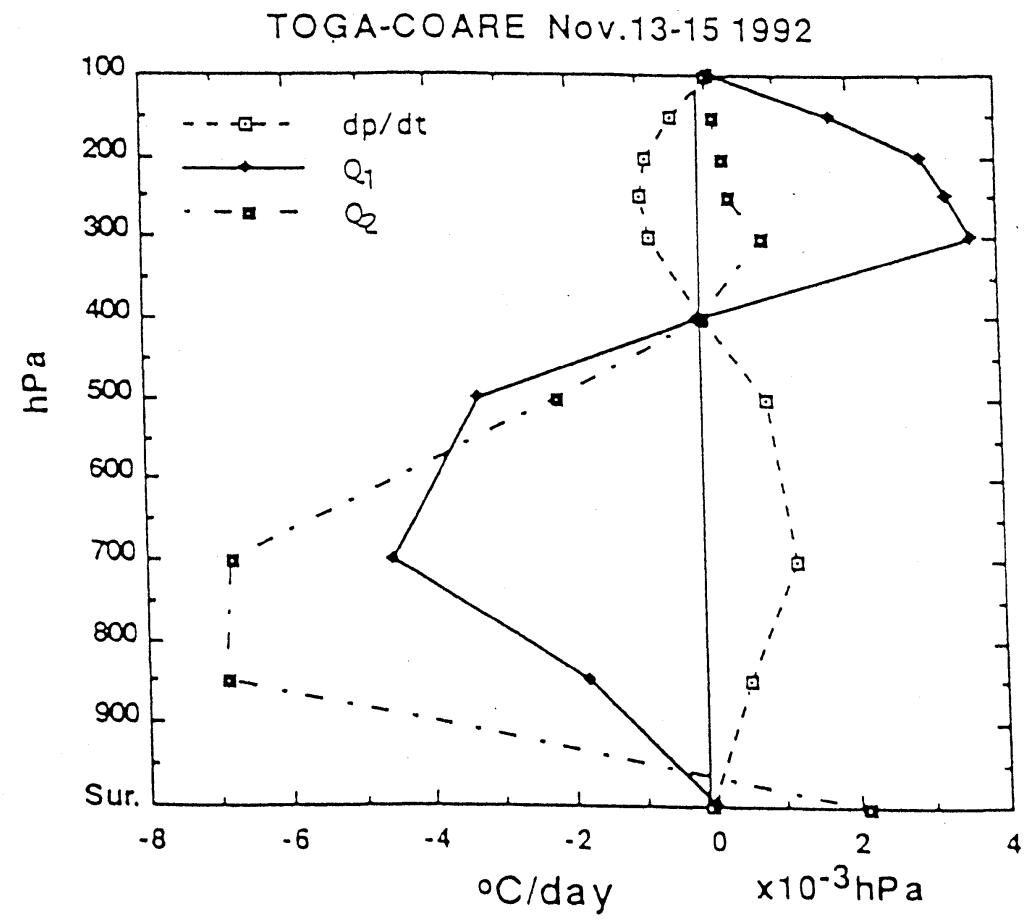

Fig. 9. (a) Mean $850 \mathrm{hPa}$ flow pattern for 13-15 November, 1992. Full lines denote the isolines of the specific humidity. The units are $\mathrm{g} / \mathrm{kg}$, and the contour interval is 1.2 unit. (b) Mean profiles of the apparent heat source $Q_{1}$ and the apparent moisture sink $Q_{2}$. The units are ${ }^{\circ} \mathrm{C} /$ day for $Q_{1}$ and $Q_{2}$, and $10^{-3} \mathrm{hPa}$ for $\omega=d p / d t$. $\omega$ is estimated based on the scheme of O'Brien (1970).

cooling and drying of the mixed layer, and warming and drying of the lower cloud layer. As portrayed in Fig. 8, in this case the depth of the mixed layer is rather shallow, with a depth of only about $30 \mathrm{hPa}$ (below $970 \mathrm{hPa}$ ).

From the above discussion, two important aspects may be pointed out. Firstly, the variable wind field caused by the tropical disturbances or cloud systems may greatly modify the structures of the mixed layer, leading to a significant decrease in its depth or even its complete disappearance. Secondly, the intrusion of dry air, especially when accompanied by 
(a)

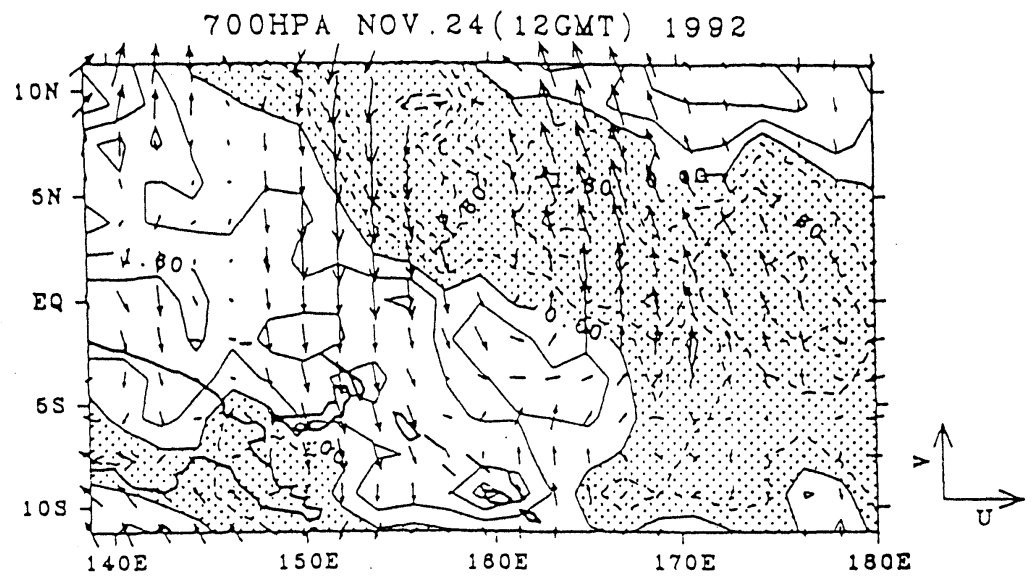

(b)

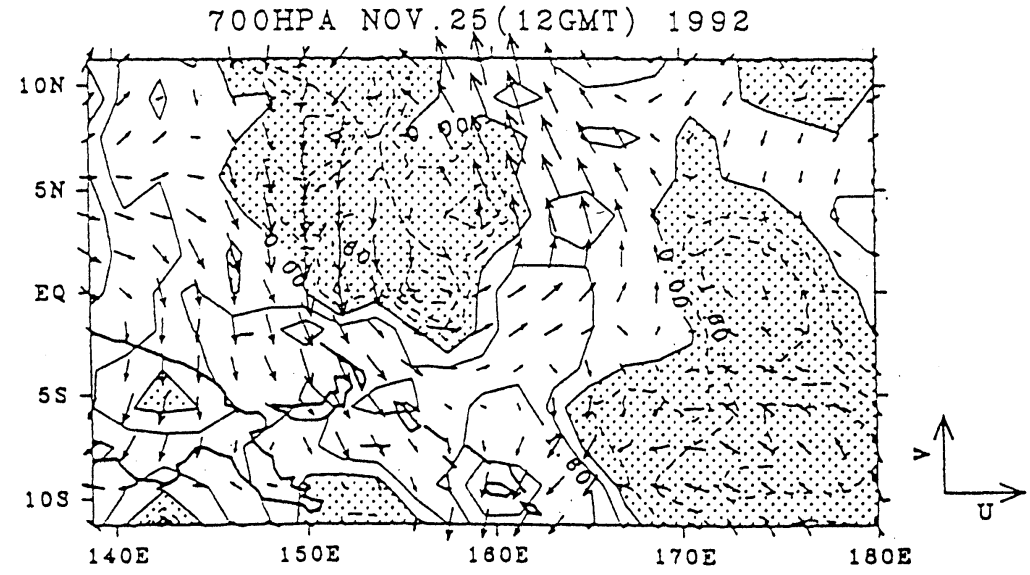

(c)

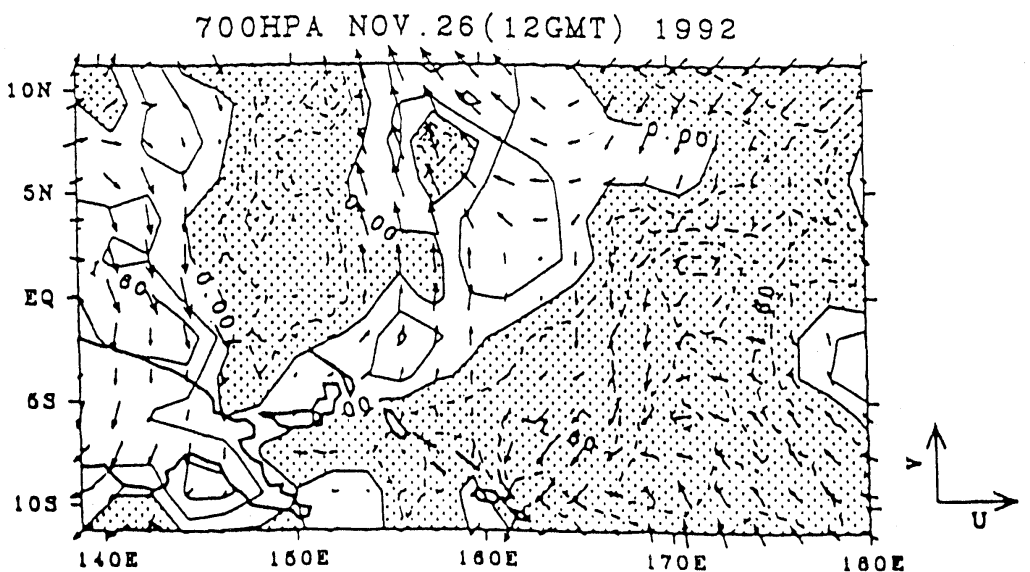

Fig. 10. (a) $700 \mathrm{hPa}$ flow pattern at $12 \mathrm{GMT}, 24$ November, 1992. Isolines denote the departure of the specific humidity field from the monthly mean field (November of 1992). The regions of negative departure are shaded. The units are $\mathrm{g} / \mathrm{kg}$ and the contour interval is 0.8 unit. (b) Same as Fig. 10a, except for 12 GMT, 25 November. (c) Same as Fig. 10a, except for 12 GMT, 26 November. 


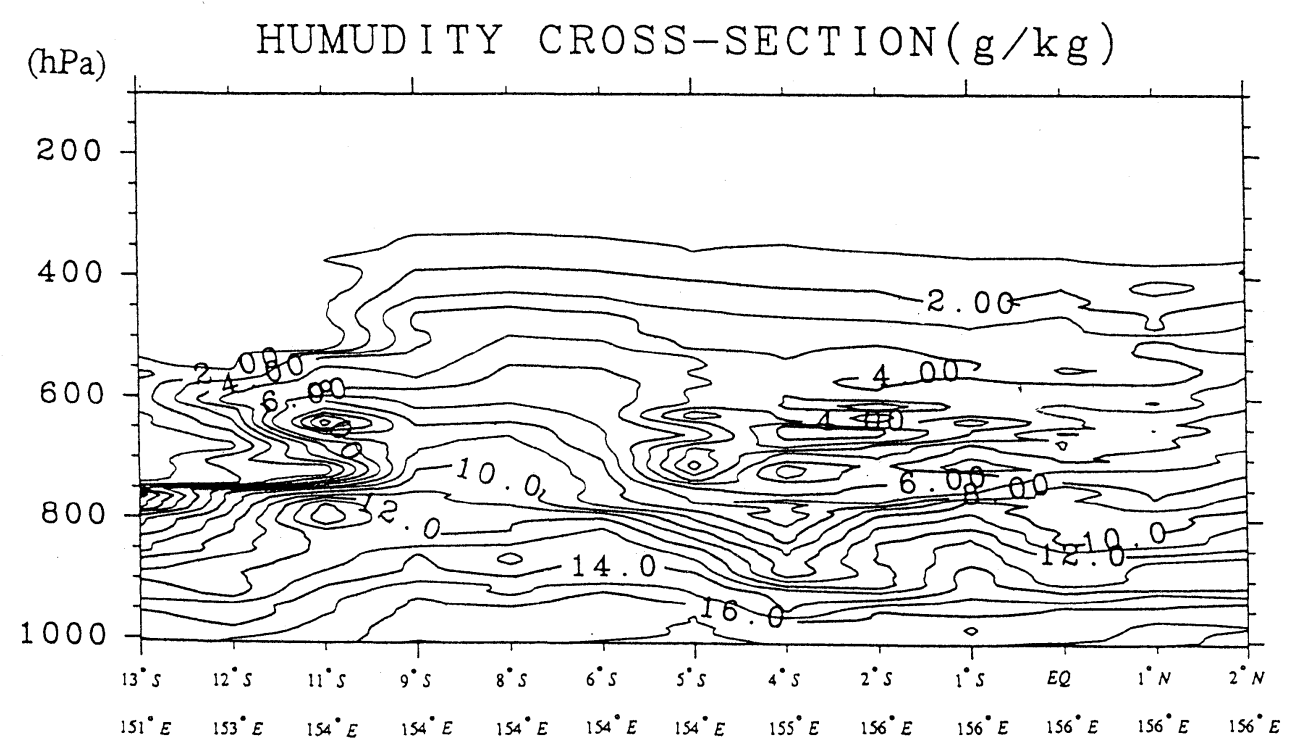

Fig. 11. Vertical cross-section along transect from $13^{\circ} \mathrm{S}, 151^{\circ} \mathrm{E}$ to $2^{\circ} \mathrm{N}, 156^{\circ} \mathrm{E}$ during $1-6$ November, 1992. Radiosonde soundings were collected from the R/V Hakuho-maru during its cruise of Leg 1. The units are $\mathrm{g} / \mathrm{kg}$, and the contour interval is 1 unit.

an east wind, may strengthen the mixed layer, with its height increasing considerably.

\section{Analysis of the Formation of Dry Layers on 13-15 and 24-26 November}

Two events of formation of an extremely dry air layer in the lower and middle troposphere highlighted the evolutional process of the mixed layer, as discussed in Section 3. Next, a further discussion of the possible cause of their formation will be presented. The formation of the first event of a dry air layer seemed to be related to a strong northward push of the cross-equatorial airflow coming from the Southern Hemisphere. From Fig. 9a, it can be clearly seen that a strong southerly wind around $150^{\circ} \mathrm{E}$ was crossing the equator and penetrating into the tropical regions of the Northern Hemisphere. The strong northward push may often cause the pre-existing ITCZ in the near-equatorial area to move northward and to become quite active, with several tropical cyclones formed along the ITCZ (Tao et al., 1983). Under the condition of this study, two tropical cyclones were observed around $10^{\circ} \mathrm{N}$. To the south of these two cyclones and to east of the southerly cross-equatorial air flow, there was an equatorial anticyclone centered at $0^{\circ}, 155^{\circ} \mathrm{E}$, where an extremely dry condition existed. The thus-formed equatorial anticyclone corresponded to a north-south oriented highpressure belt on the pressure field (not shown). This equatorial anticyclone was formed according to the conservation law of absolute vorticity $\left(\frac{d \eta}{d t}=\right.$, where $\eta=f+\zeta$ is the absolute vorticity, $\zeta$ is the relative vorticity and $f$ is the Coriolis parameter). When the southerly cross-equatorial airflow moves northward, $f$ increases and at the same time $\zeta$ decreases in order to conserve the absolute vorticity, thus leading to the generation of anticyclonic vorticity. Over the area of the equatorial anticyclone, descending motion occurred (Fig. 10b). In the lower and middle troposphere, there was cooling (apparent heat source $Q_{1}<0$ ) and evaporation (apparent moisture sink $Q_{2}<0$ ), reflecting the cloud-free or dry condition. The GMS satellite cloud imagery well documented this situation. The estimates of $Q_{1}$ and $Q_{2}$ were made according to Yanai et al. (1973).

The formation of the second event of dry air layer has been discussed by Numaguti and Takayabu (1993). They related this dry layer event to the propagation of the mixed Rossby-gravity wave (MRG) from east to west in the east trade region. Further evidence is provided here to document the effect of this movable synoptic-scale cyclonic disturbance. From Fig. 10a-10c), one can clearly see that a vortex moved westward, accompanied by a pair of northwest-southeast oriented dry bands and wet bands. At the forward side, the northerly wind prevailed and then turned into a west wind over the equatorial region. The southern part of the dry band passed over the R/V Hakuho-maru at about 00GMT 25 November, causing the rapid decrease of moisture around this observational site. At 12 GMT, 26 November, the dry band moved over the ship and the vortex became ill-organized, then the wet condition recovered again. Therefore, the advective effect is possibly of primary importance in the production of the dry condition. 
(a)

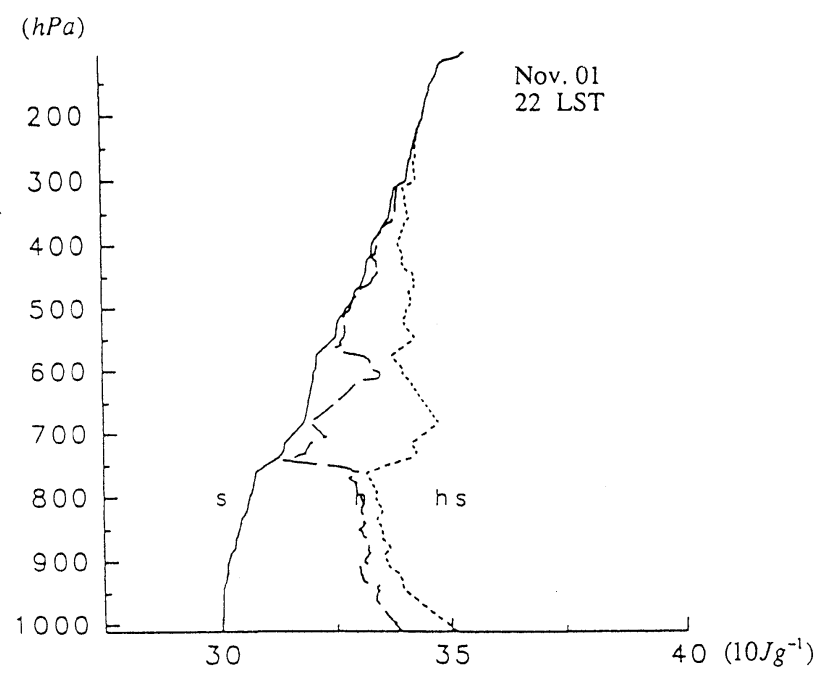

(b)

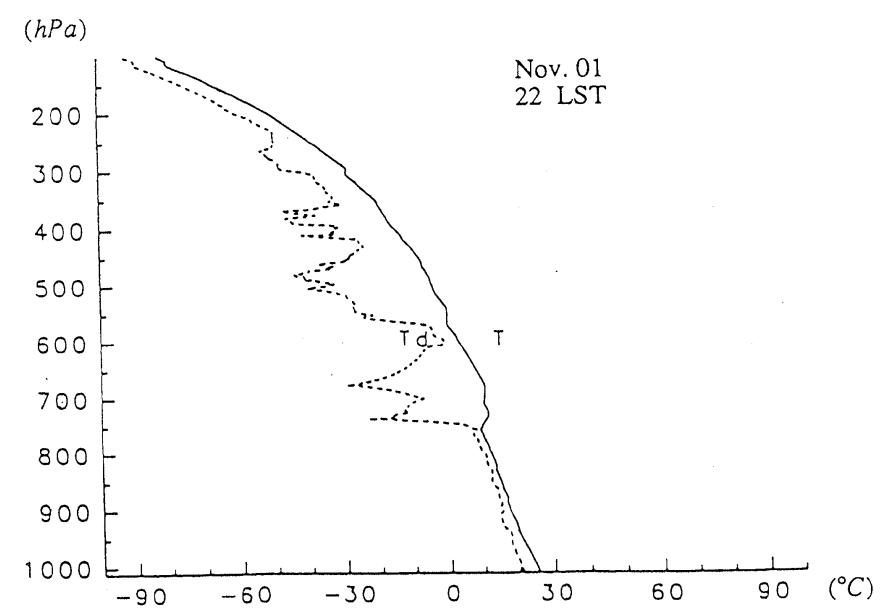

Fig. 12. (a) Same as Fig. 5a, except for $22 \mathrm{LST}, 1$ November, 1992 and the site of $13^{\circ} \mathrm{S}, 152^{\circ}$ E. (b) Same as Fig. 12a, except for profiles of $\mathrm{T}$ and $\mathrm{T}_{\mathrm{d}}$. The units are ${ }^{\circ} \mathrm{C}$.

\section{Comparisons with the Mixed Layer over Other Regions}

Besides the observations at the fixed site $\left(0^{\circ}\right.$, $\left.156^{\circ} \mathrm{E}\right)$, the $\mathrm{R} / \mathrm{V}$ Hakuho-maru also conducted omegasonde soundings regularly along its Leg 1 cruise track (in the Southern Hemisphere) and the cruise track back to Tokyo from 30 November to 4 December, 1992. The vertical cross-sections in the Southern Hemisphere transect from about $13^{\circ} \mathrm{S}$, $151^{\circ} \mathrm{E}$ to $2^{\circ} \mathrm{N}, 156^{\circ} \mathrm{E}$ and in the Northern Hemisphere transect from $1^{\circ} \mathrm{N}, 156^{\circ} \mathrm{E}$ to $25^{\circ} \mathrm{N}, 143^{\circ} \mathrm{E}$ were made to examine the spatial variations of the mixed layers. From Fig. 11, it can be seen that three zones of different moisture condition may be identified: the first dry zone between $\left(13^{\circ} \mathrm{S}, 151^{\circ} \mathrm{E}\right)$ and $\left(9^{\circ} \mathrm{S}, 154^{\circ} \mathrm{E}\right)$, the wet zone between $\left(9^{\circ} \mathrm{S}, 154^{\circ} \mathrm{E}\right)$ and $\left(5^{\circ} \mathrm{S}, 154^{\circ} \mathrm{E}\right)$ and the near-equatorial dry zone. These dry zones are characterized by the existence of dry air between $750 \mathrm{hPa}$ and $600 \mathrm{hPa}$.

In the first dry zone, the heights of the mixed layer reached $750 \mathrm{hPa}(\sim 2.5 \mathrm{~km})$, with nearly constant $\mathrm{s}$ and $\mathrm{q}$ and slightly decreasing $\mathrm{h}$ with height (see, Fig. 12). For the lower part of the mixed layer, below $940 \mathrm{hPa}(\sim 500 \mathrm{~m})$, s and q were constant with height, and upward from this level the s and q assumed a weak vertical gradient, indicating the possible existence of a cloud layer from 940 to $750 \mathrm{hPa}$. The sounding profile of $\mathrm{T}$ and $\mathrm{T}_{\mathrm{d}}$ also showed a saturation layer from 940 to $750 \mathrm{hPa}$. Above the top of the cloud layer, the deep dry layer and a nearisothermal layer existed. The LCL was at $946 \mathrm{hPa}$ $(570 \mathrm{~m})$. Therefore, the height of LCL is in coincidence with the top of the mixed layer of constant $\mathrm{s}$ 


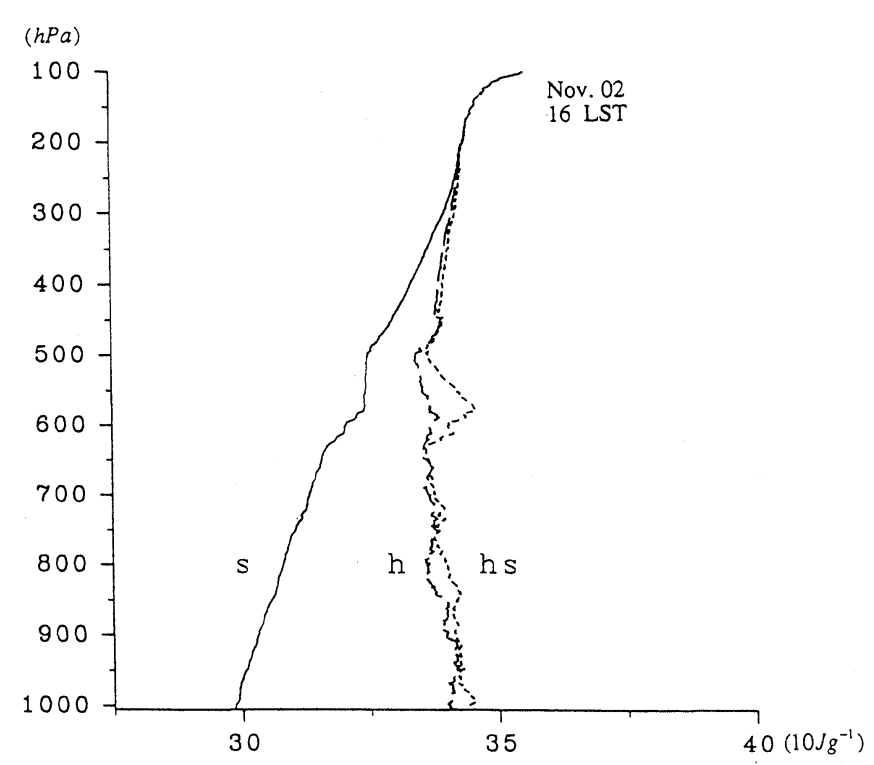

Fig. 13. Same as Fig. 5a, except for $16 \mathrm{LST}, 2$ November, 1992 and the site of $\sim 9^{\circ} \mathrm{S}, 153^{\circ} \mathrm{E}$.

and q.

Around $9^{\circ} \mathrm{S}, 153^{\circ} \mathrm{E}$, an extremely deep (the surface to $100 \mathrm{hPa}$ ) moist layer (Fig. 13) was observed with the mixed layer undetectabde and s and $\mathrm{q}$ decreasing monotorially with height. This condition possibly implied the existence of deep precipitating clouds. The wind (northeasterly wind) was nearly mixed below $700 \mathrm{hPa}$ (not shown). The LCL was very low $(\sim 100 \mathrm{~m})$, quite close to the surface. In the near-equatorial dry zone, the feature of the trade type mixed layer obviously emerged, with its general height located at about $950 \mathrm{hPa}(\sim 400-500 \mathrm{~m})$ and a dry layer capping it (not shown).

The vertical cross-section of $q$ along the Northern Hemisphere transect also showed three distinctly different zones: the near-equatorial dry zone between $1^{\circ}$ and $7^{\circ} \mathrm{N}$, the subtropical dry zone between $12^{\circ}$ and $24^{\circ} \mathrm{N}$ and the moist zone in between. Some typical sounding profiles (Fig. 14) were selected to illustrate features of their mixed layers. In the near-equatorial dry zone, the height of mixed layers reached $850 \mathrm{hPa}$, above which a capping dry and near-isothermal layer existed. The constant $\mathrm{s}$ and $q$ layer or the sub-cloud layer only extended to $950 \mathrm{hPa}$, implying the existence of a cloud layer between 950 and $850 \mathrm{hPa}$.

Likewise, no mixed layer was detected in the moist case (Fig. 14b). In the entire troposphere, the air was nearly saturated. The LCL was rather low, about $202 \mathrm{~m}(989 \mathrm{hPa})$. Figure $14 \mathrm{c}$ shows that in the subtropical region where the northeasterly monsoon at low level prevailed in winter, the height of the mixed layer rapidly enhanced, reaching $770 \mathrm{hPa}$ (around $2.3 \mathrm{~km}$ ). As pointed out previously, the mixed layer may be further divided into two sublayers: the cloud layer with weak vertical gradient of $\mathrm{s}$ and $\mathrm{q}(900-700 \mathrm{hPa})$ and the sub-cloud layer with constant $\theta$ and $\mathrm{q}$ with (the surface-900 hPa). This condition of Fig. 14c is very similar to the studies of convectively mixed layer for AMTEX'74 (Ninomiya and Akiyama, 1976) and AMTEX'75 (Agee and Lomax, 1978; Nitta and So, 1980). They found that over the AMTEX area (the East China Sea and the western Pacific west of $135^{\circ} \mathrm{E}$ ) the heights of the convectively mixed layer were estimated to be in the range from $1.5 \mathrm{~km}$ to about $2.3 \mathrm{~km}$, depending upon the different synoptic situation, cloud field and sea surface temperature conditions. The profiles in Fig. 14c are located 10-20 longitudes further east if the AMTEX regions, where the northeasterly winter monsoon also prevailed. The cold air mass similarly undergoes a significant transformation process over the warmer ocean of the warm pool. It is not surprising that a similar structure of the mixed layer was observed.

\section{Concluding Remarks}

The high-resolution omegasonde soundings in time and spaced conducted by the R/V Hakuhomaru during November 1992 for TOGA-COARE IOP provided an excellent opportunity to examine the evolution and structures of the mixed layer over the equatorial Pacific region. The preliminary analysis presented herein is instructive in improving our understanding of this matter, of which very few studies have been undertaken before. From the climatological viewpoint, most of the TOGA-COARE domain is situated in the Pacific trade zone in winter, which is normally dominated by the prevailing easterly wind at low-levels and a relatively dry weather condition. The mixed layer usually has a height of $\sim 800 \mathrm{~m}$. Often a capping dry inversion is 
(a) $(h P a)$

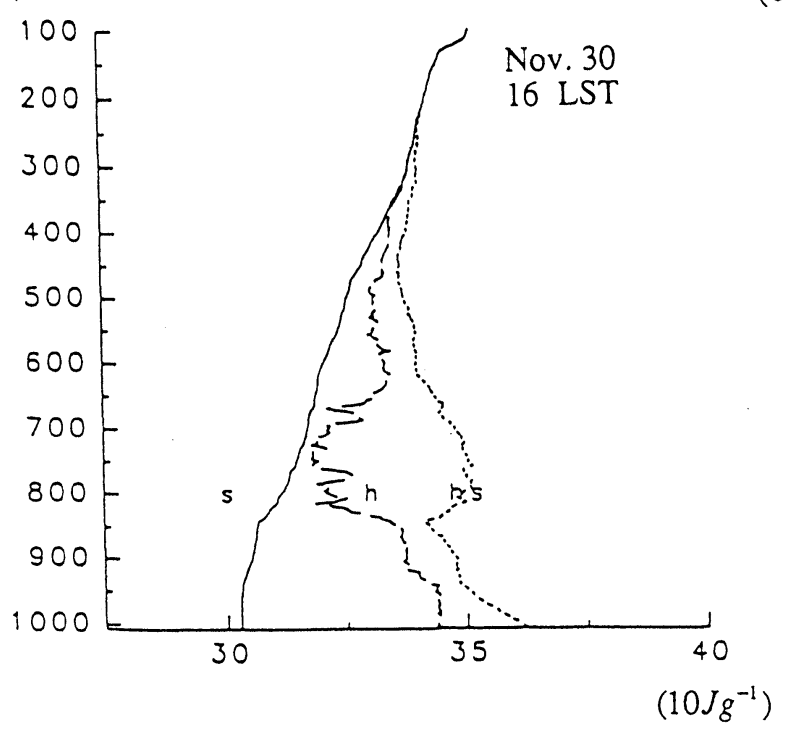

(c)

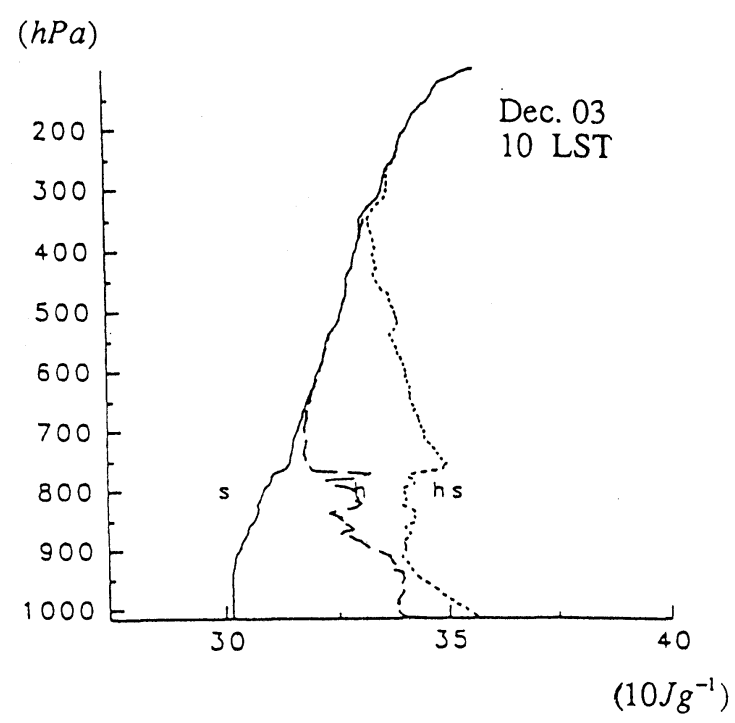

(b) $(h P a)$

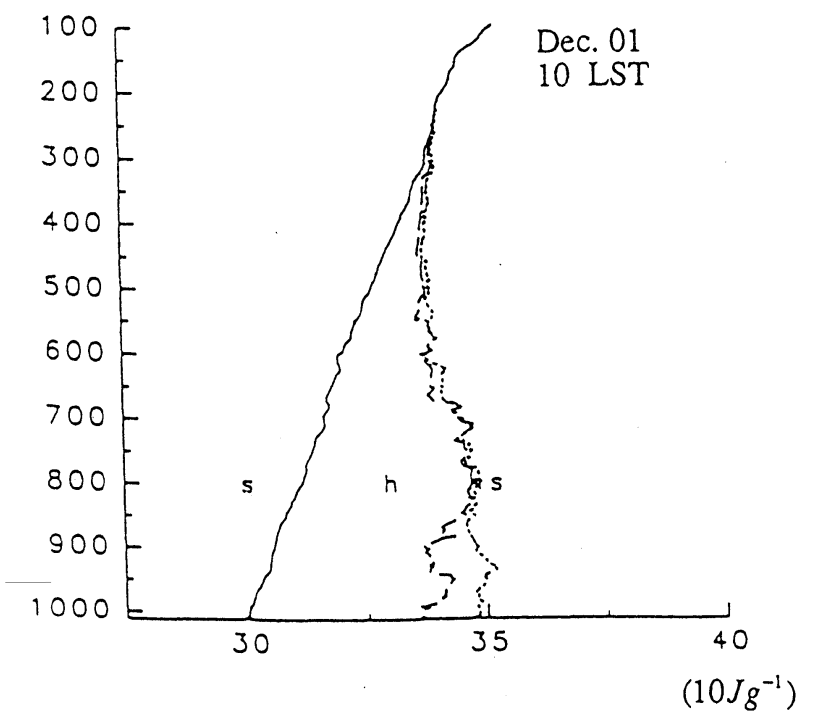

Fig. 14. (a) Same as Fig. 5a, but for 16 LST, 30 November, 1992 and the site of $6^{\circ}$ N, $147^{\circ}$ E. (b) Same as Fig. 5a, but for $10 \mathrm{LST}, 1$ December, and the site of $10^{\circ} \mathrm{N}, 141^{\circ} \mathrm{E}$. (c) Same as Fig. 5a, except for $10 \mathrm{LST}, 3$ December, 1992 and the site of $19^{\circ} \mathrm{N}, 144^{\circ} \mathrm{E}$.

observed above the mixed layer, greatly suppressing the development of convective clouds. However, this kind of normal condition was disturbed by the variable wind fields, precipitating clouds and tropical cyclone or storms. Therefore, the special emphasis of the present paper was placed on the short-term variability of the mixed layer caused by the above disturbances. The major conclusions drawn from our study have been summarized as follows:

(1) For the east trade wind régime, the height of the mixed layer, on the average, was about 800
$900 \mathrm{~m}(\sim 900 \mathrm{hPa})$. Based on the near-saturation condition below the top of the mixed layer, one may judge that a relatively thin cloud layer could exist. Above the top of the mixed layer, a dry layer normally with a thin isothermal layer, instead of an inversion, was found. In most of the cases, it is difficult to sharply divide the mixed layer into two sub-layers, as done for AMTEX region or the equatorial eastern Pacific. Therefore, the above features are to some extent different from the findings in the equatorial eastern Pacific, because there was no significant cap- 
ping inversion and a sharp subdivision of the mixed layer for TOGA-COARE region (Bond, 1992). Over the equatorial eastern Pacific, a strong inversion normally caps the mixed layer and the mixed layer may be further divided into the lower constant $\theta_{v}$ layer (from $100 \mathrm{~m}$ to $\sim 400 \mathrm{~m}$ ) and the upper sub-layer of slightly increasing $\theta_{v}$ with height $(400-900 \mathrm{~m})$. Bond (1992) defined the lower constant $\theta_{v}$ layer as the mixed layer. However, according to the definition used here and by other investigators (Ninomiya and Akiyama, 1976; Nitta and So, 1980), the depth of the mixed layer may include the upper sub-layer, thus leading to a higher mixed layer. For our case its depth reached $\sim 900 \mathrm{~m}$. Therefore, the height of the mixed layer derived in the present study is just slightly lower than its counterpart in the equatorial eastern Pacific under the east trade condition.

(2) During the observational period of 11-27 November when the vessel was fixed at $\left(0^{\circ}, 156^{\circ} \mathrm{E}\right)$, four westerly wind episodes interrupted the east trade condition. For the west wind régime, the structure of the mixed layer was greatly modified, with its height significantly depressed, normally down to $940-970 \mathrm{hPa}(\sim 300-400 \mathrm{~m})$ and even completely disappearing. A quite deep nearsaturation layer was observed, possibly implying the existence of precipitating clouds. Most of the westerly wind episodes are believed to be accompanied by eastward-propagating super cloud cluster systems (Lau, Nakazawa and Sumi, 1991). In our case, westerly winds are associated with synoptic disturbances in the Northern Hemisphere. In addition, in the regions of $5^{\circ}-10^{\circ}$ latitudes away from the equator, deep saturation layers extending in the entire troposphere were also found. The heights of their mixed layers were very low or even non-existent. Due to the fact that they formed under the east wind condition, the factors leading to suppression of the mixed layer may be other than as in the case of westerly wind.

(3) The mixed layer was greatly perturbed by two events of intrusion of an extremely dry air layer in the lower and middle troposphere which might be initiated by the northward push of a southerly crossequatorial aircurrent and the westward propagation of a tropical cyclone, respectively. In these cases, in particular for the event of 13-15 November, the mixed layer was greatly enhanced, with the height elevated up to $850 \mathrm{hPa}(\sim 1.5 \mathrm{~km})$ and a clear subdivision of two sub-layers and cloud sub-layers) are found. Above the mixed layer, there existed a considerably deep layer of extremely dry air. No strong inversion was found, only a thin near-isothermal structure.

(4) An examination of the mixed layer over other regions along the track of the ship cruise has revealed a rather complicated structure of the mixed layer, which can be considered to be due to local or regional features. Over the sub-tropical area of the Northern Hemisphere around $140^{\circ} \mathrm{E}$, the mixed layer reached a great height of $\sim 2.3 \mathrm{~km}$, nearly comparable to the condition during AMTEX which is located $20^{\circ}$ in longitude west from the present observation.

\section{Acknowledgments}

The authors would like to express their gratitude to Prof. T. Nitta for his suggestions. Sincere thanks most be paid to Prof. Asai and other staff members of the Ocean Research Institute, University of Tokyo for preparing and conducting the Hakuhomaru Cruise (KH-92-5). The authors also thank the participants in $\mathrm{KH}-5$ cruise for conducting the observations.

\section{References}

Agee, E.A. and F.E. Lomax, 1978: Structure of the mixed layer and inversion layer associated with pattern of mesoscale cellular convection during AMTEX'75. J. Atmos. Sci., 35, 2281-2301.

Asai, T., 1993: Preliminary Report of the Hakuho-maru cruise KH-92-5 (TOGA-COARE Cruise), Ocean Research Institute, Univ. of Tokyo.

Barnett, T.P., 1983: Interaction of the monsoon and Pacific trade wind system at interannual time scales. Part: The equatorial zone. Mon. Wea. Rev., 111, 756-773.

Bond, N.A., 1992: Observations of planetary boundarylayer structure in the eastern equatorial Pacific. $J$. Climate, 5, 699-706.

Brummer, B., 1978: Mass and energy budgets of a $1 \mathrm{~km}$ high atmospheric box over the GATE-scale triangle during undisturbed and disturbed weather conditions. J. Atmos. Sci., 35, 997-1011.

Chu, P.S., 1988: Extratropical forcing and the burst of equatorial westerlies in the Western Pacific: A synoptic study. J. Meteor. Soc. Japan, 66, 549-564.

Delcroix, T., G. Eldin, M. Mcphaden and A. Morliere, 1993: Effects of westerly wind bursts upon the western equatorial Pacific Ocean. J. Geophys. Res., 98, 16379-16385.

Ding, Y.H. and A. Sumi, 1995: Large-scale atmospheric circulation features during TOGA-COARE IOP. $J$. Meteor. Soc. Japan, 73, 339-351.

Ding, Y.H., A. Sumi and X.S. Shen, 1995: Structures of the mixed layer and estimates of sea surface fluxes during TOGA-COARE IOP. Part II: Estimates of sea surface fluxes. J. Meteor. Soc. Japan, 73, 585596.

Lau, K.-M., T. Nakazawa and C.H. Sui, 1991: Observations of cloud cluster hierarchies over the tropical western Pacific. J. Geophys. Res., 96, 3196-3208.

Ninomiya, K. and T. Akiyama, 1976: Structure and heat energy budget of mixed layer capped by inversion during the period of polar outbreak over Kuroshio region. J. Meteor. Soc. Japan, 54, 160-174.

Nitta, T. and S.S. So, 1980: Structure and heat, moisture and momentum budgets of a convective mixed layer during AMTEX'75. J. Meteor. Soc. Japan, 58, 378-393. 
Numaguti, A. and Y. Takayabu, 1993: The disturbances of the mixed Rossby-gravity waves in the equatorial Pacific: A case study during TOGA-COARE IOP. Preprint of Proceeding of the Autumn Meeting of Japanese Meteorological Society, A118.

O'Brien, J.J., 1970: Alternative solution to the classical vertical velocity problem J. Appl. Met., 9, 197-203.

Riehl, H., C. Yeh, and J.S. Malkus, 1951: The northeast trade of the Pacific Ocean. Quart. J. Met. Soc., 77, $598-626$.

Tao, S.Y., S.X. He and Z.F. Yang, 1883: An observa- tional study on the onset of the summer monsoon over eastern Asia in 1979. Sci. Atmos. Sinica, 7, 345-355 (in Chinese).

Wyrtki, K., 1975: El Nino - The dynamic response of the equatorial Pacific Ocean to atmospheric forcing. J. Phys. Oceanogr., 5, 572-584.

Yanai, M., S. Esbensen, and J.H. Chu, 1973: Determination of bulk properties of tropical cloud clusters from large-scale heat and moisture budget. J. Atmos. Sci., 30, 611-627.

\section{TOGA-COARE 集中観測期間中の混合層の構造と海面フラックスの評価 第 1 部 混合層の構造}

\section{丁 一匯 ${ }^{1} \cdot$ 住 明正・沈 学順}

(東京大学気候システム研究センター)

TOGA-COARE 集中観測期間中に、東大海洋研の白鳳丸が東経 156 度の赤道に於いて、1992 年 11 月 11 日から 27 日にかけて定点観測を行った。この時の海上気象観測、及び、高層気象観測を用いて混合層の変 化及び構造の解析と海面フラックスの評価が行われた。

論文の第 1 部は、混合層の変化、及び、構造が論じられている。主な結果は貿易風の東風の時には、混 合層高度は比較的高く、多くの場合は、800-900 m 程度であり、その上に乾燥した空気がかぶさっている。 しかし、ほとんど顕著な逆転層は見あたらなかった。一方、擾乱に伴う西風の場合には、混合層高度は相 当程度に低く抑えられ、あるいは、無くなっていた。深い湿潤層がしばしば観測された。

非常に乾燥した空気の進入が 2 例観測された。この際には、混合層高度が上昇し $1.5 \mathrm{~km}$ にも達した。こ の乾燥空気の侵入についても議論されている。

\footnotetext{
${ }^{1}$ 中国気象研より出張
} 